Самолюк Н. М. ${ }^{[1 ; 0 R C I D ~ I D: 0000-0001-8693-8558], ~}$ к.е.н., доцент, Міщук В. А. ${ }^{[1 ;}$ ORCID ID: 0000-0003-3626-5652], здобувач вищої освіти першого (бакалаврського) рівня, Найчук С. О. [2; ORCID ID: 0000-0002-7758-2462], директор з управління персоналом

${ }^{1}$ Національний університет водного господарства та природокористування, м. Рівне

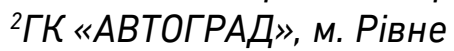

\title{
ОЦІНКА ЗАДОВОЛЕНОСТІ ПРАЦІВНИКІВ НR-БРЕНДОМ: МЕТОДИЧНІ ЗАСАДИ ТА МОЖЛИВОСТІ ЗАСТОСУВАННЯ В УПРАВЛІННІ КОМПАНІЕЮ
}

В статті обґрунтовано важливість оцінювання HR-бренду компанії в розрізі його структурних атрибутів. Запропоновано методичний підхід для оцінювання задоволеності працівників внутрішнім HR-брендом шляхом анкетування 3 використанням методу семантичного диференціалу. Аргументовано доцільність використання результатів оцінки для формування та розвитку позитивного HR-бренду компанії.

Ключові слова: HR-бренд; бренд роботодавця; атрибути HR-бренду; оцінка внутрішнього HR-бренду; тип задоволеності працівників брендом.

Постановка проблеми. Однією 3 основних характеристик сучасного ринку праці $€$ значна конкуренція між роботодавцями в процесі залучення В компанію кваліфікованих, креативних, ініціативних працівників, тобто сьогодні не лише роботодавці вибирають кандидатів, а й претенденти на посади обирають найбільш привабливе місце роботи, аналізуючи та порівнюючи оффери роботодавців. Проте лише пошуком та наймом компетентних працівників проблема не вирішується, не менш гостро стоїть питання утримання їх у компанії в довгостроковій перспективі. 3 огляду на це значна частина вітчизняних компаній почала практикувати використання новітніх інструментів для формування позитивного іміджу роботодавця, що дозволять залучити та втримувати найбільш гідних співробітників. Саме тому HR-брендинг (створення цінностей роботодавців для існуючих і потенційних працівників) став одним 3 найбільш ефективних інструментів забезпечення конкурентоспроможності компанії на ринку праці за останні роки.

Зростання ролі бренду роботодавця для залучення та закріплення в компанії компетентних працівників, а також 
посилення їх мотивації та лояльності до роботодавця обумовлює необхідність вивчення структури HR-бренду та дослідження факторів, що впливають на рівень задоволеності ним різних цільових аудиторій.

Аналіз останніх досліджень. Питанням формування, оцінювання та розвитку бренду роботодавця присвячено багато праць зарубіжних вчених: С. Берроу, Т. Амблер, Р. Мослі, Б. Мінчінгтон, П.Бертон, М. Евінг, Л. Хах, А. Вільсон, В. Мангольд, С. Дж. Майлз, С. Кінг, Д. Грейс та інші. У їх роботах досліджувалися сутність, параметри й атрибути привабливості бренду роботодавця [1; 2], роль внутрішнього брендингу в імплементації та втіленні бренду роботодавця [3], особливості формування [4; 5] та оцінювання бренду роботодавця $[6 ; 7 ; 8 ; 9 ; 10 ; 11 ; 12]$.

Серед українських науковців питання управління брендом роботодавця, викладено у працях С. Цимбалюк, В. Оберемчук, О. Сороки, К. Красовської, В. Рибінцевої, С. Мокіної та ін. Зокрема дослідження окремих аспектів оцінки бренду роботодавців висвітлюється в статтях Л. Балабанової, О. Сардак [13], Т. Білорус і С. Фірсової [14], В. Перції [15], Т. Лейні [16], О.Бруковської, Н. Осовицької [17].

Водночас, існуючі науково-методичні підходи до оцінювання бренду роботодавця, зокрема визначення показників оцінки, залишаються суперечливими і дуже часто більш придатні для використання по відношенню до бренду товару. Відтак, проблема оцінювання бренду роботодавця в цілому та за спрямованістю його на аудиторію (внутрішній та зовнішній бренд) лишається невирішеною.

Постановка завдання. 3 огляду на вищезазначене, метою даної роботи $€$ розробка методики оцінювання рівня задоволеності працівників внутрішнім HR-брендом компанії загалом та окремими його складовими.

Виклад основного матеріалу. Системна робота у сфері HRбрендингу дозволяє посилити позицію компанії серед конкурентів та сприяє зростанню їх вартості. Це зумовлено тим, що позитивний бренд роботодавця сприяє економії часових та фінансових ресурсів на закриття вакансій, зменшенню витрат за рахунок зростання лояльності працівників та скорочення їх плинності, зростанню продуктивності праці через підвищення залученості та вмотивованості персоналу.

При формуванні ефективного бренду компанії як роботодавця необхідно чітко представляти, на кого мають бути спрямовані 
програмні заходи, які для цього найкраще використовувати інструменти і що конкретно має бути отримано в кінці їх реалізації.

HR-бренд компанії спрямовується на два типи аудиторії внутрішній та зовнішній ринок праці. 3 табл. 1 видно, що під кожну аудиторію формуються свої цілі, вибираються інструменти комунікацій і плануються результати.

Таблиця 1

Особливості внутрішнього та зовнішнього бренду роботодавця [14]

\begin{tabular}{|c|c|c|}
\hline & Внутрішній HR-бренд & Зовнішній HR-бренд \\
\hline Аудиторія & наявні працівники компанії & $\begin{array}{l}\text { потенційні працівники, колишні } \\
\text { працівники, рекрутингові } \\
\text { агентства, аутсорсингові компанії } \\
\text { іт.д. }\end{array}$ \\
\hline Цілі & $\begin{array}{l}\text { - зниження рівня плинності } \\
\text { кадрів; } \\
\text { - забезпечення довгострокової } \\
\text { лояльності та залученості } \\
\text { кадрів; } \\
\text { - скорочення термінів та } \\
\text { вартості підбору персоналу; } \\
\text { - зменшення затрат на } \\
\text { адаптацію та навчання } \\
\text { персоналу }\end{array}$ & $\begin{array}{l}\text { - формування образу компанії як } \\
\text { позитивного і привабливого місця } \\
\text { для працевлаштування; } \\
\text { - залучення необхідної кількості } \\
\text { кандидатів } \\
\text { кваліфікації; } \\
\text { - підповідної } \\
\text { іміджу компанії }\end{array}$ \\
\hline $\begin{array}{l}\text { Інструменти } \\
\text { комунікацій }\end{array}$ & 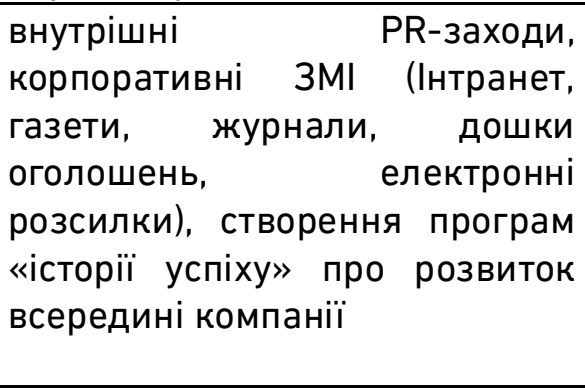 & $\begin{array}{l}\text { зовнішні PR-заходи, реклама, } \\
\text { публікація вакансій в ЗMI, участь } \\
\text { в ярмарках вакансій, участь у } \\
\text { зовнішніх рейтингах на звання } \\
\text { кращого роботодавця, залучення } \\
\text { аудиторії в соціальних мережах, } \\
\text { кар'єрний сайт, } \\
\text { «адвокати бренду» }\end{array}$ \\
\hline Результат & $\begin{array}{lr}\text { підвищення } & \text { лояльності та } \\
\text { залученості } & \text { працівників, } \\
\text { підвищення } & \text { продуктивності } \\
\text { праці, зменшення плинності } \\
\text { кадрів, } \\
\text { задоволеності } \\
\text { гордість за роботодавця }\end{array}$ & $\begin{array}{l}\text { залучення найкращих цільових } \\
\text { кандидатів на ринку праці, } \\
\text { сформований образ підприємства } \\
\text { як найбільш привабливого місця } \\
\text { для роботи }\end{array}$ \\
\hline
\end{tabular}

Джерело: побудовано авторами на основі [18].

Однак, з огляду на визначені характеристики можна прийти до висновку, що між зовнішнім та внутрішнім брендами компанії як роботодавця повинні існувати тісні функціональні зв'язки, оскільки їх розбіжність може викликати недовіру до організації та ії позиціонуванню як роботодавця.

Аналіз підходів до структури бренду роботодавця дав змогу виокремити чотири блоки атрибутів, які оцінюються на внутрішньому та зовнішньому ринку праці і над якими в компанії варто працювати, 
а саме: організаційний, функціональний, економічний та психологічний. В табл. 2 виокремлено ключові атрибути даних блоків.

Таблиця 2

Атрибути HR-бренду компанії

\begin{tabular}{|c|c|}
\hline Організаційні атрибути & Функціональні атрибути \\
\hline $\begin{array}{l}\text { - позиція компанії на ринку; } \\
\text { - впізнаваність корпоративного та } \\
\text { споживчих брендів; } \\
\text { - ступінь доступності інформації про } \\
\text { компанію для потенційних працівників; } \\
\text { - імідж і репутація топменеджменту; } \\
\text { - місце та зручність розташування офісу }\end{array}$ & $\begin{array}{l}\text { - зміст роботи; } \\
\text { - можливості навчання та } \\
\text { професійного розвитку; } \\
\text { - перспективи кар'єрного зростання; } \\
\text { - об'єктивність в оцінці роботи з боку } \\
\text { керівників; } \\
\text { - можливість участі у прийнятті } \\
\text { оперативних та стратегічних рішень }\end{array}$ \\
\hline Економічні атрибути & Психологічні атрибути \\
\hline $\begin{array}{l}\text { - рівень оплати праці; } \\
\text { - гарантія стабільності зайнятості; } \\
\text { - графік роботи; } \\
\text { - умови праці та рівень організації } \\
\text { робочого місця; } \\
\text { - соціальний пакет }\end{array}$ & $\begin{array}{l}\text { - корпоративна культура; } \\
\text { - зовнішній вигляд офісу та персоналу } \\
\text { компанії; } \\
\text { - соціально-психологічний клімат у } \\
\text { колективі; } \\
\text { - стиль управління; } \\
\text { - відсутність непотизму («кумівства») }\end{array}$ \\
\hline
\end{tabular}

Варто відмітити, що HR-бренду компанії можна оцінювати використовуючи різноманітні критерії розроблені як практиками та i науковцями [12; 14]. Наприклад, консультанти премії «HR-бренд»Осовицька Н. та Бруковська О., пропонують оцінювати результативність бренду роботодавця за такими критеріями [17]:

1) внутрішній бренд роботодавця: рівень залученості, задоволеності та лояльності співробітників, плинність персоналу, кількість кандидатів за рекомендацією співробітників, зниження кількості лікарняних листів;

2) зовнішній бренд роботодавця: привабливість на думку кандидатів, зменшення витрат та скорочення терміну закриття вакансії, кількість якісних вхідних резюме, відгуки кандидатів та рекрутингових агентств, моніторинг інформації про компанію в Інтернеті (блоги, форуми, сайти, соціальні мережі).

HR-брендинг необхідно розпочинати із оцінки реального стану речей з цього питання всередині компанії. Зокрема, варто виявити наскільки працівники задоволенні кадровою політикою, чи планують вони звільнятися (якщо планують, то чому?), чи рекомендують вони компанію як роботодавця для своїх знайомих і т.д. Відтак, спробуємо оцінити внутрішній бренд компанії як роботодавця на основі дослідження рівня задоволеності та лояльності їі працівників.

Наше дослідження було проведено на базі ТОВ «Вік-Експо», що входить до ГК «Автоград», що вже понад 25 років працює на ринку 
Рівненської області. На сьогодні «Вік-Експо» $є$ офіційним дилером таких автомобільних брендів, як SKODA, Renault, Nissan, Honda, Fiat та BOSCH. В автосалонах компанії клієнти можуть придбати модельні ряди зазначених брендів, у авторизованих СТО - отримати послуги гарантійного та післягарантійного обслуговування, а також придбати запасні частини та аксесуари, послуги мийки, сервіс-мобіля i евакуатора.

Діагностику внутрішнього HR-бренду було здійснено за даними онлайн-анкетування працівників компанії 3 використанням доповненої нами методики Білорус Т. та Фірсової С. Оцінювання рівня задоволеності працівників внутрішнім HR-брендом здійснювалося за атрибутами, об'єднаними у 4 блоки: організаційні, функціональні, економічні та психологічні [14]. Google-форма анкети була надіслана усім працівникам автоцентру і впродовж тижня було отримано 42 відповіді, тобто $30 \%$ персоналу автоцентру взяли участь у дослідженні.

Методика, на якій базується діагностика HR-бренду, містить семантичний диференціал із п'ятирозмірною шкалою розрядів між двома біполярними твердженнями (5 - «абсолютно погоджуюся»; 1 «абсолютно не погоджуюся»). Шкала дозволяє респондентам як найточніше оцінити своє ставлення до різних складових, що характеризують внутрішній бренд роботодавця. Загальна сума балів набрана працівником за анкетою характеризує рівень його задоволеності від внутрішнього HR-бренду. Отже, залежно від кількості складових бренду, що оцінювалися працівниками (у нас їх 37), та від можливої їх оцінки (від 1 до 5) рівень задоволеності може варіюватися від 37 до 180 балів, а саме:

- 145-180 балів - стабільна задоволеність HR-брендом працівник задоволений, оскільки знайшов у компанії все те, на що очікував;

- 109-144 балів - нестабільна задоволеність HR-брендом працівник досягнув більшість своїх цілей у компанії, але залишається незадоволеним, оскільки очікував від компанії більшого;

- 73-108 балів - раціональна задоволеність HR-брендом працівник задоволений тим, що має в компанії, хоча й не досягну усіх своїх цілей;

- 37-72 балів - конструктивна незадоволеність HR-брендом працівник поки що не досяг своїх цілей у компанії, але впевнений, що досягне;

- до 37 балів - стабільна незадоволеність HR-брендом працівник не досягнув своїх цілей в компанії і впевнений, що змінити нічого неможливо.

За результатами анкетування ми визначили розподілили 
працівників за рівнем задоволеності внутрішнім HR-брендом компанії (рисунок).

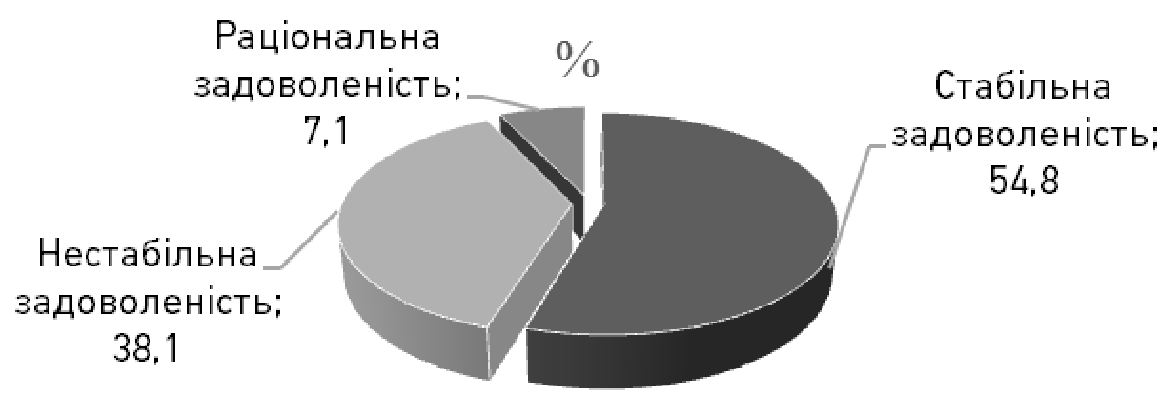

Рисунок. Розподіл працівників компанії за рівнем задоволеності внутрішнім HR-брендом

Як бачимо, для більшої половини респондентів характерна стабільна задоволеність загальним брендом роботодавця, тобто їх потреби в даній компанії повністю задовольняються. Проте, для $41 \%$ працівників характерна нестабільна задоволеність, тобто на даний час компанія не повною мірою змогла задовільнити їх очікування. При цьому 7,7\% опитаних працівників задоволені компанією, хоча і не досягли усіх цілей, що пов'язували з роботою там. Важливим моментом $€$ те, що працівників, які були б незадоволені загальним внутрішнім HR-брендом компанії, немає. Відтак загальний бренд товариства як роботодавця серед внутрішньої аудиторії знаходиться на високому рівні.

Однак, оцінка задоволеності загальним брендом $\epsilon$ недостатньою. Важливо продіагностувати задоволеність різними ключовими елементами бренду, адже це дасть змогу керівникам компанії розробити чітку програму дій щодо подальшого розвитку позитивного внутрішнього HR-бренду. 3 табл. 3 можна побачити, що стабільна задоволеність організаційними та психологічними атрибутами характерна відповідно для 71,4 та $69 \%$ респондентів. При цьому атрибутами, що входять до функціонального та економічного блоків, стабільно задоволеними $€$ менше половини опитаних працівників. Крім того, серед респондентів знайшлися i такі, для яких характерна нестабільна задоволеність усіма блоками атрибутів, і такі, у яких тип задоволеності був раціональним. Небезпечним сигналом $€$ те, що для 2,4\% респондентів характерна конструктивна незадоволеність економічними атрибутами, а це потребує більш детального дослідження. 
Таблиця 3

Розподіл працівників компанії за типом задоволеності атрибутами внутрішнього HR-бренду, \%

\begin{tabular}{|c|c|c|c|c|}
\hline Тип & \multicolumn{4}{|c|}{ Атрибути HR-бренду } \\
\cline { 2 - 5 } задоволеності & організаційні & функціональні & економічні & психологічні \\
\hline $\begin{array}{c}\text { Стабільна задоволеність } \\
\text { (С3) }\end{array}$ & 71,4 & 47,6 & 35,7 & 69,0 \\
\hline $\begin{array}{c}\text { Нестабільна } \\
\text { задоволеність (Н3) }\end{array}$ & 26,2 & 40,5 & 40,5 & 31,0 \\
\hline $\begin{array}{c}\text { Раціональна } \\
\text { задоволеність (Р3) }\end{array}$ & 2,4 & 11,9 & 21,4 & 0 \\
\hline $\begin{array}{c}\text { Конструктивна } \\
\text { незадоволеність (КН3) }\end{array}$ & 0 & 0 & 2,4 & 0 \\
\hline $\begin{array}{c}\text { Стабільна } \\
\text { незадоволеність (СН3) }\end{array}$ & 0 & 0 & 0 & 0 \\
\hline
\end{tabular}

Для визначення типу задоволеності працівників кожним окремим атрибутом, нами розроблено шкалу (табл. 4), що базується на кількості респондентів, що заповнили анкети.

Таблиця 4 Шкала визначення типу задоволеності кожним окремим атрибутом

\begin{tabular}{|c|c|c|c|c|c|}
\hline & \multicolumn{5}{|c|}{ Тип задоволеності } \\
\cline { 2 - 6 } & $\mathrm{CH} 3$ & $\mathrm{KH} 3$ & $\mathrm{P} 3$ & $\mathrm{H} 3$ & $\mathrm{CH}$ \\
\hline Бали & до 43 & $43-84$ & $85-126$ & $127-168$ & $169-210$ \\
\hline
\end{tabular}

Організаційний блок включає 10 характеристик, і як видно 3 табл. 5, рівнем реалізації дев'яти атрибутів працівники компанії стабільно задоволені. Водночас $€$ певні проблеми щодо залучення та утримання в компанії талановитих співробітників, адже багато респондентів рівню реалізації даного атрибуту присвоїли «1-3».

Таблиця 5

Розподіл працівників компанії за типом задоволеності організаційними атрибутами внутрішнього HR-бренду, \%

\begin{tabular}{|c|c|c|c|c|c|c|c|}
\hline \multirow{2}{*}{ Характеристики блоку } & \multicolumn{5}{|c|}{ Оцінка } & \multirow{2}{*}{$\begin{array}{c}\Sigma \\
\text { балів }\end{array}$} & \multirow{2}{*}{$\begin{array}{c}\text { Тип } \\
\text { задов }\end{array}$} \\
\hline & «5» & «4» & $\ll 3 »$ & $\ll 2 »$ & $\ll 1 »$ & & \\
\hline 1 & 2 & 3 & 4 & 5 & 6 & 7 & 8 \\
\hline $\begin{array}{c}\text { Я готовий порекомендувати компанію } \\
\text { як роботодавця своїм друзям }\end{array}$ & 47,6 & 40,5 & 9,5 & 2,4 & 0,0 & 182 & C3 \\
\hline $\begin{array}{c}\text { Я вважаю, що компанія робить усе } \\
\text { можливе для залучення та утримання } \\
\text { талановитих співробітників }\end{array}$ & 23,8 & 19,0 & 42,9 & 2,4 & 4,8 & 153 & H3 \\
\hline $\begin{array}{c}\text { Я вважаю, що керівництво піклується } \\
\text { про імідж та репутацію компанії }\end{array}$ & 66,7 & 31,0 & 2,4 & 0,0 & 0,0 & 195 & C3 \\
\hline
\end{tabular}


продовження табл. 5

\begin{tabular}{|c|c|c|c|c|c|c|c|}
\hline $\begin{array}{c}\text { Я вважаю, що компанія приділяє дос- } \\
\text { татньо уваги питанням інформування } \\
\text { потенційних працівників про компанію }\end{array}$ & 42,9 & 31,0 & 19,0 & 7,1 & 0,0 & 172 & $\mathbf{C 3}$ \\
\hline $\begin{array}{c}\text { Я вважаю, що компанія має власний } \\
\text { впізнаваний корпоративний бренд }\end{array}$ & 71,4 & 21,4 & 4,8 & 0,0 & 2,4 & 193 & $\mathbf{C 3}$ \\
\hline $\begin{array}{c}\text { Я вважаю, що компанія має } \\
\text { розгалужену мережу інформаційних } \\
\text { засобів комунікації }\end{array}$ & 59,5 & 26,2 & 11,9 & 2,4 & 0,0 & 186 & $\mathbf{C 3}$ \\
\hline $\begin{array}{c}\text { Я вважаю, що компанія підтримує } \\
\text { позитивний образ роботодавця }\end{array}$ & 54,8 & 31,0 & 7,1 & 7,1 & 0,0 & 182 & $\mathbf{C 3}$ \\
\hline $\begin{array}{c}\text { Я вважаю, що компанію можна } \\
\text { охарактеризувати як роботодавця з } \\
\text { активною соціальною позицією }\end{array}$ & 52,4 & 31,0 & 14,3 & 2,4 & 0,0 & 182 & $\mathbf{C 3}$ \\
\hline $\begin{array}{c}\text { Я вважаю, що місце та зручність } \\
\text { розташування офісу єодатковою } \\
\text { конкурентною перевагою бренду } \\
\text { компанії як роботодавця }\end{array}$ & 52,4 & 16,7 & 28,6 & 2,4 & 0,0 & 176 & $\mathbf{C 3}$ \\
\hline $\begin{array}{c}\text { Я вважаю, що компанія займає стійкі } \\
\text { позиції на ринку праці та має стабільну } \\
\text { частку на своєму товарному ринку }\end{array}$ & 66,7 & 21,4 & 9,5 & 2,4 & 0,0 & 190 & $\mathbf{C 3}$ \\
\hline
\end{tabular}

Що стосується психологічних атрибутів, то тут ситуація найкраща i, як видно з табл. 6, для усіх 10 характеристик працівники присвоїли високий рівень реалізації - в основному «4» і «5». Відтак, щодо кожного психологічного атрибуту для респондентів характерна стабільна задоволеність.

Таблиця 6

Розподіл працівників компанії за типом задоволеності психологічними атрибутами внутрішнього HR-бренду, \%

\begin{tabular}{|c|c|c|c|c|c|c|c|}
\hline \multirow{2}{*}{ Характеристики блоку } & \multicolumn{5}{|c|}{ Оцінка } & \multirow{2}{*}{$\sum_{\text {балів }}^{\sum}$} & \multirow{2}{*}{$\begin{array}{l}\text { Тип } \\
\text { задов. }\end{array}$} \\
\hline & «5» & «4» & «3» & «2» & «1» & & \\
\hline Я поділяю цінності компанії & 69,0 & 16,7 & 14,3 & 0,0 & 0,0 & 191 & C3 \\
\hline $\begin{array}{c}\text { Я вважаю, що компанія має сильну } \\
\text { корпоративну культуру }\end{array}$ & 64,3 & 26,2 & 7,1 & 2,4 & 0,0 & 190 & C3 \\
\hline $\begin{array}{c}\text { Під час спілкування з колегами я } \\
\text { не боюся висловлювати власну } \\
\text { думку }\end{array}$ & 42,9 & 42,9 & 11,9 & 2,4 & 0,0 & 179 & C3 \\
\hline $\begin{array}{l}\text { У колективі рідко бувають } \\
\text { конфлікти }\end{array}$ & 83,3 & 11,9 & 4,8 & 0,0 & 0,0 & 201 & C3 \\
\hline $\begin{array}{c}\text { Я вважаю, що відносини з } \\
\text { керівництвом у компанії базуються } \\
\text { на взаємоповазі }\end{array}$ & 52,4 & 35,7 & 9,5 & 2,4 & 0,0 & 184 & C3 \\
\hline $\begin{array}{c}\text { Я вважаю, що керівництво } \\
\text { справедливо ставиться до всіх } \\
\text { членів колективу }\end{array}$ & 38,1 & 38,1 & 16,7 & 4,8 & 2,4 & 170 & C3 \\
\hline
\end{tabular}


продовження табл. 6

\begin{tabular}{|c|c|c|c|c|c|c|c|}
\hline $\begin{array}{c}\text { Якби в мене була можливість } \\
\text { змінити керівника, я б нею HЕ } \\
\text { скористався }\end{array}$ & 61,9 & 16,7 & 9,5 & 4,8 & 7,1 & 177 & $\mathbf{C 3}$ \\
\hline $\begin{array}{c}\text { Колеги/керівник завжди } \\
\text { допомагають у вирішенні будь- } \\
\text { яких питань }\end{array}$ & 52,4 & 38,1 & 9,5 & 0,0 & 0,0 & 186 & $\mathbf{C 3}$ \\
\hline $\begin{array}{c}\text { Я вважаю, що зовнішній вигляд } \\
\text { офісу (персоналу) компанії } \\
\text { стимулює працівників ефективно } \\
\text { виконувати поставлені завдання }\end{array}$ & 45,2 & 40,5 & 7,1 & 2,4 & 4,8 & 176 & $\mathbf{C 3}$ \\
\hline $\begin{array}{c}\text { Я вважаю, що відсутність } \\
\text { «кумівства» дає компанії } \\
\text { можливість відбирати найкращих } \\
\text { працівників та ефективно ними } \\
\text { управляти }\end{array}$ & 59,5 & 21,4 & 9,5 & 2,4 & 7,1 & 178 & $\mathbf{C 3}$ \\
\hline
\end{tabular}

Водночас оцінка респондентами функціональних атрибутів HRбренду $\epsilon$ дещо гіршою. Як бачимо з табл. 7 у працівників виникають питання щодо фінансування компанією їх професійного навчання, а також щодо можливості впливати на прийняття управлінських рішень. Також значна частина працівників не вважає, що компанія розглядає їх слабкі сторони, як можливості для подальшого розвитку. Тому не дивно, що за цими атрибутами для працівників характерний нестабільний тип задоволення. Крім того, більшість респондентів переконані в тому, що система оцінювання персоналу в компанії потребує змін, що відобразилося на їх задоволеності цим атрибутом.

Таблиця 7

Розподіл працівників компанії за типом задоволеності функціональними атрибутами внутрішнього HR-бренду, \%

\begin{tabular}{|c|c|c|c|c|c|c|c|}
\hline \multirow{2}{*}{ Характеристики блоку } & \multicolumn{5}{|c|}{ Оцінка } & \multirow{2}{*}{$\begin{array}{c}\Sigma \\
\text { балів } \\
\end{array}$} & \multirow{2}{*}{$\begin{array}{l}\text { Тип } \\
\text { задов. }\end{array}$} \\
\hline & «5» & «4» & «3» & «2» & «1» & & \\
\hline $\begin{array}{c}\text { У компанії приділяють достатньо } \\
\text { уваги навчанню та розвитку } \\
\text { персоналу }\end{array}$ & 45,2 & 35,7 & 16,7 & 2,4 & 0,0 & 178 & C3 \\
\hline $\begin{array}{c}\text { Якою мірою компанія фінансує } \\
\text { професійне навчання, необхідне } \\
\text { для виконання функціональних } \\
\text { обов'язків }\end{array}$ & 38,1 & 14,3 & 33,3 & 11,9 & 2,4 & 157 & H3 \\
\hline $\begin{array}{c}\text { Компанія надає можливості для } \\
\text { кар'єрного зростання }\end{array}$ & 42,9 & 31,0 & 16,7 & 9,5 & 0,0 & 171 & C3 \\
\hline $\begin{array}{c}\text { Керівництво стимулює працівників } \\
\text { до кар'єрного зростання }\end{array}$ & 45,2 & 26,2 & 19,0 & 9,5 & 0,0 & 171 & C3 \\
\hline
\end{tabular}


продовження табл. 7

\begin{tabular}{|c|c|c|c|c|c|c|c|}
\hline $\begin{array}{c}\text { Компанія розглядає слабкі сторони } \\
\text { працівника, виявлені в результаті } \\
\text { оцінювання, як можливості для } \\
\text { подальшого розвитку }\end{array}$ & 40,5 & 35,7 & 7,1 & 7,1 & 9,5 & 164 & H3 \\
\hline $\begin{array}{c}\text { Я вважаю, що система оцінювання } \\
\text { НЕ вимагає вдосконалення }\end{array}$ & 23,8 & 23,8 & 21,4 & 16,7 & 14,3 & 137 & H3 \\
\hline $\begin{array}{c}\text { Компанія надає змістовний } \\
\text { зворотний зв'язок за результатами } \\
\text { оцінювання }\end{array}$ & 45,2 & 33,3 & 11,9 & 2,4 & 7,1 & 171 & $\mathbf{C 3}$ \\
\hline $\begin{array}{c}\text { Я вважаю, що керівництво компанії } \\
\text { заохочує працівників до участі в } \\
\text { процесі прийняття управлінських } \\
\text { рішень }\end{array}$ & 31,0 & 35,7 & 19,0 & 9,5 & 4,8 & 159 & H3 \\
\hline $\begin{array}{c}\text { Я вважаю, що працівники компанії } \\
\text { за потреби мають можливість } \\
\text { самостійно визначати методи та } \\
\text { інструменти виконання } \\
\text { поставлених завдань }\end{array}$ & 50,0 & 21,4 & 21,4 & 0,0 & 7,1 & 171 & $\mathbf{C 3}$ \\
\hline
\end{tabular}

Найбільше невдоволення у працівників компанії викликав рівень реалізації економічних атрибутів системи управління персоналом. Лише за трьома із семи атрибутів працівники стабільно задоволені, а ще для трьох складових економічного блоку характерний нестабільний тип задоволення. Однак, хоча більшість працівників і вважає, що система оплати праці в компанії $\epsilon$ справедливою та прозорою, але значна їх частина схиляється до того, що її необхідно змінити (табл. 8).

Таблиця 8

Розподіл працівників компанії за типом задоволеності економічними атрибутами внутрішнього HR-бренду, \%

\begin{tabular}{|c|c|c|c|c|c|c|c|}
\hline \multirow{2}{*}{ Характеристики блоку } & \multicolumn{5}{|c|}{ Оцінка } & $\begin{array}{c}\text { б } \\
\text { бип }\end{array}$ \\
\cline { 2 - 8 } & «5» & «4» & «3» & «2» & «1» & балів & задов. \\
\hline $\begin{array}{c}\text { Я вважаю заробітну плату в } \\
\text { компанії конкурентною в } \\
\text { порівнянні з іншими компаніями } \\
\text { цієї галузі }\end{array}$ & 26,2 & 26,2 & 21,4 & 23,8 & 2,4 & 147 & H3 \\
\hline $\begin{array}{c}\text { Я вважаю, що система оплати } \\
\text { праці в компанії є справедливою } \\
\text { та прозорою }\end{array}$ & 33,3 & 21,4 & 26,2 & 19,0 & 0,0 & 155 & H3 \\
\hline $\begin{array}{c}\text { Я вважаю, що систему оплати праці } \\
\text { в компанії необхідно залишити без } \\
\text { змін }\end{array}$ & 11,9 & 28,6 & 14,3 & 19,0 & 26,2 & 118 & P3 \\
\hline $\begin{array}{c}\text { Я задоволений соціальним } \\
\text { пакетом, який пропонує компанія }\end{array}$ & 35,7 & 19,0 & 31,0 & 7,1 & 7,1 & 155 & H3 \\
\hline
\end{tabular}




\begin{tabular}{|c|c|c|c|c|c|c|c|}
\hline $\begin{array}{c}\text { Робота в компанії передбачає } \\
\text { легальну зайнятість та } \\
\text { дотримання державних } \\
\text { соціальних гарантій для } \\
\text { працівників }\end{array}$ & 45,2 & 35,7 & 9,5 & 4,8 & 4,8 & 173 & $\mathbf{C 3}$ \\
\hline $\begin{array}{c}\text { Я вважаю, що керівництво } \\
\text { компанії піклується про умови } \\
\text { праці та відпочинку в компанії }\end{array}$ & 52,4 & 26,2 & 9,5 & 9,5 & 2,4 & 175 & $\mathbf{C 3}$ \\
\hline $\begin{array}{c}\text { Я вважаю, що облаштування мого } \\
\text { робочого місця дозволяє мені } \\
\text { ефективно виконувати поставлені } \\
\text { завдання }\end{array}$ & 40,5 & 45,2 & 11,9 & 2,4 & 0,0 & 178 & $\mathbf{C 3}$ \\
\hline
\end{tabular}

Аналіз результатів оцінювання дозволив виявити декілька проблемних моментів в системі управління персоналом (оплата праці та оцінювання персоналу), що потребують удосконалення. Тож дана методика оцінювання може бути використана керівниками ТОВ «ВікЕкспо» для розроблення й обґрунтування управлінських рішень щодо оптимізації розвитку їхнього внутрішнього HR-бренду.

Висновки. Сучасні тенденції ринку праці показують, що компанії, котрі не приділяють достатньо уваги формуванню позитивного бренду на ринку праці, не тільки не можуть залучити компетентних фахівців, а й ризикують втратити наявних. Бренд роботодавця підкреслює унікальні аспекти зайнятості в компанії та пропозицію цінності для наявних і потенційних працівників. Відтак сильний HR-бренд забезпечує компанії привабливий образ як на зовнішньому ринку праці, що дозволяє залучати найбільш кваліфікованих спеціалістів, так і на внутрішньому ринку праці, що формує лояльність і залученість працівників і впливає на подальший успішний розвиток компанії [18].

Для ефективного розвитку HR-бренду важливо проводити постійний моніторинг мотивів вибору потенційними працівниками роботодавців, а також вивчати причини їх утримання в компанії. Водночас отримані результати необхідно використовуватися для прийняття подальших управлінських рішень в цьому напрямку.

Проведена нами діагностика внутрішнього HR-бренду TOB «ВікЕкспо» показала, що загальний рівень задоволеності працівників брендом компанії як роботодавця є надзвичайно високим. Водночас аналіз рівня задоволеності різними структурними елементами (атрибутами) бренду дозволив виявити декілька проблемних моментів в системі управління персоналом, що потребують удосконалення. 
1. Ambler T., Barrow S. The employer brand. The Journal of Brand Management. 1996. № 4. Pp. 185-206. 2. Berthon P., Ewing M., Hah L. Captivating Company: Dimensions of Attractiveness in Employer Branding. International Journal of Advertising. 2005. Vol. 24. № 2. Pp. 151-172. 3. Punjaisri K., \& Wilson A. The role of internal branding in the delivery of employee brand promise. Journal of Brand Management. 2007. 15(1). Pp. 57-70. 4. King C., \& Grace D. Building and measuring employee-based brand equity. European Journal of Marketing. 2010. 44(7/8). Pp. 938-971. 5. Mangold W. G., Miles S. J. The employee brand: Is yours an all-star? Business Horizons. 2007. 50(5). Pp. 423-433. 6. Barrow S., Mosley R. The Employer Brand : Bringing the Best of Brand Management to People at Work. Wiley. 2005. 232 p. 7. Ванэкен Б. Бренд помощь / пер. с англ. СПб. : Питер, 2005. 336 с. 8. Бойетт Д. Гуру маркетинга / пер. с англ. М. : Эксмо. 2004. 320 с. 9. ЛеПла Дж. Стратегия развития бренда: Оригинальный практический инструментарий для лидерства вашего бренда. Днепропетровск : Баланс-Клуб, 2004. 384 с. 10. Дэвис С., Данн М. Бренд-билдинг / пер. с англ. под ред. В. Домнина. СПб. : Питер, 2005. 320 с. 11. King C., Grace D. Examining the antecedents of positive employee brand-related attitudes and behaviours. European Journal of Marketing. 2012. 46(3/4). Рp. 469-488. 12. Мансуров Р. HR-брендинг. Как повысить эффективность персонала. Санкт-Петербург : БХВ-Петербург, 2011. 13. Балабанова Л. В., Сардак О.В. Діагностика конкурентоспроможності бренду підприємства-роботодавця. Економічний часопис-XXI. 2014. № 1-2(1). С. 94-97. 14. Білорус Т. В., Фірсова С.Г. Методичний інструментарій оцінювання рівня задоволеності працівників внутрішнім HR-брендом компанії. Проблеми системного підходу в економіці випуск. 2020. Вип. 2(76). С. 54-61. 15. Перция В. Брендинг: курс молодого бойца. СПб. : Питер, 2005. 208 с. 16. Лейни Т. А., Семенова Е. А., Шилина С. А. Бренд-менеджмент : учеб.-практ. пособие. М. : Дашков и Ко, 2010. 228 с. 17. Осовицкая H., Бруковская О. Как построить HR-Бренд вашей компании. 53 способа повысить привлекательность компании-работодателя. Питер, 2010. 288 с. 18. Мокіна С. М. Бренд роботодавця як інструмент підвищення ефективності використання персоналу на підприємствах молочної промисловості : автореф. дис. ... канд. екон. наук : 08.00.04. Київ, 2015. 22 с.

\section{REFERENCES:}

1. Ambler T., Barrow S. The employer brand. The Journal of Brand Management. 1996. № 4. Pp. 185-206. 2. Berthon P., Ewing M., Hah L. Captivating Company: Dimensions of Attractiveness in Employer Branding. International Journal of Advertising. 2005. Vol. 24. № 2. Pp. 151-172. 3. Punjaisri K., \& Wilson A. The role of internal branding in the delivery of employee brand promise. Journal of Brand Management. 2007. 15(1). Pp. 57-70. 4. King C., \& Grace D. Building and measuring employee-based brand equity. European Journal of Marketing. 2010. 44(7/8). Pp. 938-971. 5. Mangold W. G., Miles S. J. The employee brand: Is yours an all-star? Business Horizons. 2007. 50(5). Pp. 423-433. 6. Barrow S., Mosley R. The Employer Brand: Bringing the Best of Brand Management to People at Work. Wiley. 2005. 232 p. 7. Vaneken B. Brend pomosch / per. S angl. SPb. : Piter, 2005. 336 s. 8. Boyett D. Guru marketinga / per. s angl. M. : Eksmo. 2004. 320 s. 9. LePla Dj. Strategiya razvitiya brenda: Originalnyiy prakticheskiy instrumentariy dlya liderstva vashego brenda. Dnepropetrovsk: Balans-Klub, 2004. 384 s. 10. Devis S., Dann M. Brend-bilding / per. s angl. pod red. V. Domnina. SPb. : Piter, 2005. 320 s. 11. King C., Grace D. Examining the antecedents of positive employee brand-related attitudes and behaviours. European Journal of Marketing. 
2012. 46(3/4). Pp. 469-488. 12. Mansurov R. HR-brending. Kak povyisit effektivnost personala. Sankt-Peterburg: BHV-Peterburg, 2011. 13. Balabanova L. V., Sardak O. V. Diahnostyka konkurentospromozhnosti brendu pidpryiemstva-robotodavtsia. Ekonomichnyi chasopys-XXI. 2014. № 1-2(1). S. 94-97. 14. Bilorus T. V., Firsova S. H. Metodychnyi instrumentarii otsiniuvannia rivnia zadovolenosti pratsivnykiv vnutrishnim HR-brendom kompanii. Problemy systemnoho pidkhodu $v$ ekonomitsi vypusk. 2020. Vyp. 2(76). S. 54-61. 15. Pertsiya V. Brending: kurs molodogo boytsa. SPb. : Piter, 2005. 208 s. 16. Leyni T. A., Semenova E. A., SHilina S. A. Brendmenedjment : ucheb.-prakt. posobie. M. : Dashkov i Ko, 2010. 228 s. 17. Osovitskaya N., Brukovskaya 0. Kak postroit HR-Brend vashey kompanii. 53 sposoba povyisit privlekatelnost kompanii-rabotodatelya. Piter, 2010. 288 s. 18. Mokina S. M. Brend robotodavtsia yak instrument pidvyshchennia efektyvnosti vykorystannia personalu na pidpryiemstvakh molochnoi promyslovosti : avtoref. dys. ... kand. ekon. nauk : 08.00.04. Kyiv, 2015. $22 \mathrm{~s}$.

\section{Samoliuk N. M. [1; ORCID ID: 0000-0001-8693-8558], Candidate of Economics (Ph.D.), Associate Professor, Mishchuk V. A. [1; ORCID ID: 0000-0003-3626-5652], Senior Student, Naichuk S. 0. [2; ORCID ID: 0000-0002-7758-2462], Director of Personnel Management}

${ }^{1}$ National University of Water and Environmental Engineering, Rivne ${ }^{2} G C$ «AUTOGRAD», Rivne

\section{ASSESSMENT OF EMPLOYEE SATISFACTION WITH HR BRAND: METHODOLOGICAL PRINCIPLES AND POSSIBILITIES OF USE IN COMPANY MANAGEMENT}

The growing role of the HR brand to ensure the competitiveness of the company in the labor market necessitates the study of factors that influence the level of satisfaction of various target audiences.

It is recommended to assess the level of employee satisfaction with the internal HR brand based on organizational, functional, economic and psychological blocks of attributes. It is proposed to use a methodology that contains a five-dimensional scale that allows employees accurately assess their attitudes to the various attributes of the employer's brand. The total amount of points scored by the employee on the questionnaire characterizes the level of his satisfaction with the internal HR brand. It is noted that the assessment of satisfaction with the overall brand is insufficient. It is important to diagnose satisfaction with the various key elements of the brand, as this will allow company managers to develop a clear program of actions for the further development of a positive internal HR brand.

The diagnostics of the internal HR-brand of «Vik-Expo» LLC showed that the overall level of employee satisfaction with the company's brand as 
an employer is extremely high. At the same time, the analysis of the level of satisfaction with the various attributes of the brand revealed several problematic issues in the personnel management system, which in turn should be improved according to the obtained results. Particularly, there is an insufficiently high level of employee satisfaction with the company's policy on attracting and retaining talented employees in the organizational unit; there is a slight dissatisfaction with the system of remuneration and compensation in the economic block; the imperfection of the personnel evaluation system that needs to be changed is revealed in the functional block. At the same time, there is a stable satisfaction with all the elements of the psychological block.

Keywords: HR-brand; employer's brand; HR-brand attributes; internal HR-brand assessment; type of employee satisfaction with the brand.

Самолюк Н. Н. [1; ORCID ID: 0000-0001-8693-8558], К.э.Н., доцент,

Мищук В. А. [1; ORCID ID: 0000-0003-3626-5652], соискатель высшего образования первого (бакалаврского) уровня, Найчук С. А. [2; ORCID ID: 0000-0002-7758-2462], директор по управлению персоналом

\footnotetext{
${ }^{1}$ Национальный университет водного хозяйства и природопользования, г. Ровно

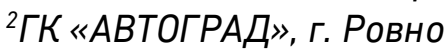

\section{ОЦЕНКА УДОВЛЕТВОРЕННОСТИ РАБОТНИКОВ НR-БРЕНДОМ: МЕТОДИЧЕСКИЕ ОСНОВЫ И ВОЗМОЖНОСТИ ИСПОЛЬЗОВАНИЯ В УПРАВЛЕНИИ КОМПАНИЕЙ}

В статье обоснована важность оценки HR-бренда компании в разрезе его структурных атрибутов. Предложен методический подход к оценке удовлетворенности работников внутренним HR-брендом путем анкетирования с использованием метода семантического дифференциала. Аргументированна целесообразность использования результатов оценки для формирования и развития положительного HRбренда компании.

Ключевые слова: HR-бренд; бренд работодателя; атрибуты HRбренда; оценка внутреннего HR-бренда; тип удовлетворенности работников брендом. 